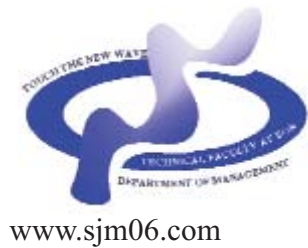

Serbian Journal of Management 8 (1) (2013) 79 - 93

\title{
RATIO ANALYSIS OF ACTUAL BUSINESS PERFORMANCE OF OPEN INVESTMENT FUNDS IN SERBIA
}

\author{
Lidija Barjaktarovića $^{a^{*}}$, Dejan Ječmenicab and Maja Paunovićc \\ $a_{\text {University Singidunum, Faculty of economics, finance and administration, }}$ \\ Bulevar Vojvode Misica 43, 11000 Belgrade, Serbia

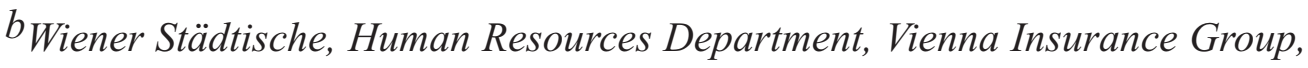 \\ Tresnjinog cveta 1, Belgrade, Serbia \\ ${ }^{c}$ Union Nikola Tesla University, Faculty for management, \\ Njegoseva 1a, 21000 Sremski Karlovci, Serbia
}

(Received 10 January 2013; accepeted 10 April 2013)

\begin{abstract}
The subject of this paper is to analyze the performance of open investment funds in Serbia in the period of 2007 to 2013. By applying Jensen's alpha, Sharper and Sortino ratio it was found that the performances of domestic investment funds are unsatisfactory. Review of investment funds operations is based on the returns they bring and the risks they accept in the business. In Serbia, the equity funds, as the most risky funds, started to operate in 2007, while cash funds (as the least risky funds) were introduced in later phase after 3 years. At the moment there are 16 open investment funds (on 02/28/13), where value growth and value maintenance funds dominate. A total net asset of open investment funds is 2,324 million Dinars i.e. 20 million Euros (at the end of 2012).
\end{abstract}

Keywords: investment funds, interest rate, risk, Jensen's alpha, Sharper ratio, Sortino ratio

\section{INTRODUCTION}

Investment funds are collective investment institutions which raise individual investors' funds and invest them in a wide range of financial assets. Investment funds offer their members a range of benefits and professional investment management, and for their service charge fee. The basic concept of investment funds is the pooling of individual investors funds, in order for them to achieve the benefits resulting from the

\footnotetext{
* Corresponding author: lbarjaktarovic@singidunum.ac.rs
}

DOI: $10.5937 /$ sjm8-3275 
large scale investing, as well as the benefits of sharing the costs of investment.

Open investment fund is an institution of joint venture funds that invests assets of the fund as financial assets through financial markets, and for the fund members it issues investment units that represent claims on the part of the fund assets. Open funds continuously issue and sell their own shares to investors, but they continuously purchase them on their demand.

Investment funds are the eldest financial institutions on Serbian market. Local regulation allowed their establishment at the end of 2006, but the first investment fund started operations in the first quartile of 2007. It is later comparing other countries in surrounding - in Croatia, they were established in 1997, in Bosnia and Herzegovina they started operations in 2000, etc. (Republic of Serbia Securities Commission, 2013).

If we analyse the Serbian financial market in the terms of balance assets, we can notice that the banks are the most dominant players with more than $90.8 \%$ of market share; insurance companies took $3 \%$ of the market share and other participants took the rest financial institutions (NBS, 2013), such as leasing companies, brokerage houses, pension funds, investment funds, etc.

The topic of this paper is to analyze the performance achieved by the open investment funds in Serbia in the period of 2007 to 2013, with special focus on the period from 2007 to 2010 due to the consistency of existence of open investment funds (in terms of type, number and particular open investment fund). Review of operations of investment funds is based on the returns they bring and the risks they accept in the business.

\section{LITERATURE REVIEW}

Though capital structure literature is replete with studies in the developed and selected developing countries, there is a dearth of similar studies on how the development in the financial environment of a firm affects financing decisions firms (Doku et al., 2011). In the last decade investment funds became important institutional investor on global financial markets. The most important role has open investment funds (The Investment Company Institute, 2007). Today in the world there are 70,000 open investment funds with the total asset above 25 trillion dollars at the end of 2011 (The Investment Company Institute, 2011). In Serbia investment funds are new investment alternative, which has been available since 2007 (Barjaktarovic et al., 2012a).

The big increase of investment funds popularization in the world, and to the assets subject of their management, had impact on development of different measures which will estimate their performance. In order to provide long term existence open investment funds should take care about portfolio structure (management), i.e. investment of assets under management in adequate financial instruments taking in consideration diversification, liquidity of instrument, interest and risk (Haslem, 2010). It is important to analyse investment funds' revenue with the accepted risks (Luckoff, 2011). Moreover, Luckoff (2011) distinguished total and systematic risk, and applied it on particular portfolio and its elements. Finally, he emphasized that performance measures of open investment funds can be considered as: ratio numbers, alpha measures and measures based on 
benchmarks. In accordance with accepted risk and generated revenue American citizen invests 37,000 dollars in investment fund; Slovenian's citizen invests 968 Euros in investment fund, Croatian citizen invests 464 Euros in investment fund, while Serbian citizen invests less than 1 Euro in investment fund (Bifoline, 2012).

According to Vejnovic (2011) investment in Serbian investment funds were not good alternative until 2010. Also, Serbian investment funds had bed performances if we analyse the achieved revenue in accordance with the accepted risk. Portfolio managers of Serbian open investment funds did not manage to add the value to the active portfolio management. Also, he emphasized that the industry of Serbian open investment funds were not developed and competitive comparing to the region. These facts were confirmed in research done by Barjaktarovic et al (2012).

The effects of the world economic crisis were visible on all Serbian market (Jeremic, 2009). The level of debts of Serbian companies had direct impact on their profitability during the crisis (Racic et al., 2011). The majority number of companies had problems with liquidity, so they were not in position to invest free funds in investment funds. They needed financial support from different financial institutions. In Serbia, credits are the most important instrument for financing companies business. Corporative bonds, as way of financing, are in the phase of establishing. Also, the citizens and companies still prefer to invest what are available funds with term-deposits with the bank (Barjaktarovic \& Jecmenica, 2011).

\section{METODOLOGY}

Investment funds subject of analysis will be: Delta Plus, Delta Dynamic, Erste Cash, Erste Euro Balanced, Fima Proactive, FimaNovac, Citadel Novcani fond, Citadel Triumph Balance, Citadel Triumph, Focus premium, Ilirika Global, Kombank In Fond and Raiffeisen Akcije. Out of scope are following investment funds: Raiffeisen cash and Raiffeisen World, because they started operations after 2010. The overview of business analysis of open investment funds in Serbia in the period of 2007 to 2013 will be given in part (chapter) 4. However, the specific analysis of performance of open investment funds will be done for the period from 2007 to 2010 (in which the open investment funds do not have the same length of business time), due to the continuity in terms of type of funds and available data (new law on equity markets and revised law on investment funds were brought and implemented in 2011) in the part (chapter) 5 .

The performance analysis of the open investment funds in Serbia (13 of 15) will be made based on the Sharpe and Sortino ratios and Jensen's alpha, which perceive the returns of investment funds in relation to the risks assumed (Microsoft Excel was used for the calculation).

Sharpe ratio was developed by the Nobel Prize Winner William Sharpe in 1966, and it is based on the CAPM model (Capital Asset Pricing Model) and on the editing of the returns for risk (Sharpe, 1966). The applied formula for the calculation is:

$S=\frac{\overline{r_{i}}-\overline{r_{f}}}{\delta_{D}}$

where:

$S$ - Sharpe ratio, 
$\bar{r}_{i}$ - Expected return rate on portfolio (investment fund) in the forthcoming period, $\overline{r_{f}}$ - Expected return rate on the risk free securities in the forthcoming period,

$D$ - Difference between $\bar{r}_{i}$ and $\overline{r_{f}}$,

$\delta_{D}$ - Standard deviation $\overline{r_{i}}-\overline{r_{f}}$.

The numerator shows the remuneration as an additional contribution, and the denominator the risk expressed by standard deviation of extra return, or total risk. Accordingly, we can immediately see that the returns of investment funds in practice often do not have normal distribution, which is the lack of method.

The results are interpreted as follows: 1) The ratio value shows how well the return on investment compensates the investors for the risk taken, 2) Positive values are good, negative bad, there is no optimal value, 3) A negative value of the extra return indicates that the fund return is worse than risk free rate, hence the performance is bad.

Sortino ratio was developed by Frank Sortino in 1994 and it measures the returns adjusted to the targeted return rate and decline risk (Sortino \& Satchell, 2001). The applied formula is:

$S_{o}=\frac{\overline{r_{i}}-M A R}{\delta_{D}(\text { downside })}$

where:

$S_{o}$ - Sortino ratio,

$\bar{r}_{i}$ - The average rate of returns on the

portfolio (investment fund) in a defined previous period,

MAR - Minimal acceptable return rate (in this paper MAR is used as risk free return rate),

$D$ - Difference between $\bar{r}_{i}-M A R$,
$d_{D}($ downside) - Standard deviation difference $\bar{r}_{i}-M A R \quad$ which has a negative preceding sign.

The numerator shows the remuneration as the extra return (compared to $M A R$ ) and the denominator the risk expressed by standard deviation of negative extra returns, or the risk of declining value of an investment. Sortino realized that the standard deviation as a risk measure punishes investment also for achieving returns that are above the risk free rate, which is why he introduced the declining risk vale (Downside risk).

The results are interpreted as follows: 1) The ratio value shows how well the return on investment compensates the investors for the risk taken, 2) Positive values are good, negative bad, there is no optimal value, 3) A negative value of the extra return indicates that the fund return is worse than risk free rate (or some other $M A R$ ), hence the performance is bad. For the analysis for this paper as a minimum acceptable rate of return a risk-free return rate will be used.

Jensen's alpha was developed by Michael Jensen in 1967, and is used to determine the abnormal return of securities or portfolio relative to its expected rate of return to a theoretical model. Jensen's alpha measures the portfolio manager's ability to achieve returns above those that are representing remuneration for carrying market risk (above the risk free rate of return). The applied formula for calculation is (Jensen, 1967):

$\alpha_{j}=r_{i}-\left[r_{f}+\beta\left(r_{m}-r_{f}\right)\right]$

where:

$\alpha_{j}$ - Jensen's alpha,

$r_{i}$ - Realized return portfolio rate (of investment fund) in some year, 
$r_{f}$ - Return rate on risk free assets in some year,

$r_{m}$ - Return rate on market portfolio (market benchmark) in some year,

$b$ - Beta portfolio coefficient (of investment fund).

Part of the formula in the large brackets is the expected return rate according to CAPM model, and $r_{i}$ is an achieved return of portfolio, i.e. the investment fund. The expected return rate is equal to sum of the return on risk free assets and the risk premium. The risk premium is the product of beta coefficient and the market risk premium. Part of the formula in large brackets indicates how much the investment fund should earn due to the risk it carries expressed by beta coefficient, and $r_{i}$ shows how much the investment fund actually earned. If the portfolio manager is able to predict future prices of securities and market trends, then he will be able to achieve higher returns than those expected according to the equation in the large brackets. The disadvantage of this measure is that it does not show the way in which good or bad performance was made.

Results interpretation: 1) Jensen's alpha value shows if the investment fund (portfolio) has the certain return in relation to the market risk it took? 2) Positive values are good, negative bad. 3) Alpha shows the part of return that should be assigned to the ability of portfolio manager to achieve abnormal return. 4) Since the investors always want to maximize their return for a certain risk level, they always look for the investments which have positive alphas. 5) A positive alpha value of an investment fund shows that its portfolio manager made good performance in market trends change prediction or the selection of undervalued securities, or both.

Information about investment funds and their achieved results will be taken over from the sites of Republic of Serbia Securities Commission, National bank of Serbia and Serbian investment funds. The bases are the historical values of investment fund units taken from the official web site of the management corporations. All results are annualized.

The formula that which be used for the average unit of the funds analyzed is:

Average unit of funds analyzed $=$

$$
\frac{\text { Sum of total investment unit }}{\text { Iumber of the funds analyzed }}
$$

Limitations to the analysis were: luck of consolidated data, short period of investment funds existence in Serbia, different period of performing business in Serbia by all analyzed funds and appearance of the world's economic crisis.

\section{OPEN INVESTMENT FUNDS IN SERBIA}

Legislation of the Republic of Serbia has enabled the investment funds establishment in late 2006. Revised version of law on investment funds was brought and implemented in 2011. In accordance with it, types of open investment funds on Serbian market were: value maintenance funds, balanced funds, asset value growth funds and return funds. Market conditions influenced existence of value maintenance funds, balanced funds and asset value growth funds. The regulator emphasized importance of equity, portfolio management, limitations in 
investing and protecting assets of open investment funds. At the same time Law on equity markets defined necessary infrastructure for stable financial market, such as equity, qualified staff, equipment, financial instruments, terms and conditions for trade, risk management, etc. (Republic of Serbia Securities Commission, 2013).

Delta Plus is the first (equity) investment fund that was started in March 2007. At the end of 2007, six investment funds operated in Serbia, managed by the same number of management corporations.

After 2007 there is a growth in the number of available open funds, and in the first two months of 2013 there were 16 open investment funds registered which are still managed by four of the management corporations (total assets under management are 24.1 million Euros on 02/28/2013; NBS, 2013). Meanwhile, six open investment funds were closed or merged with another fund. The emergence of a number of funds with a constant number of management corporations can be interpreted as the desire of the corporations to meet different investors' preferences towards investors' risk in Serbia (the movements of open investment funds registered in Serbia and value of assets under management is shown in Figure 1).

If we analyze market situation (shown in Figure 2), we can conclude that the strongest and safest position on Serbian market have open investment funds established by commercial banks (such as Raiffeisen, Erste and Komercijalna bank). They hold $85.72 \%$ of market share in terms of assets under management on 02/28/13 (NBS, 2013). Raiffeisen's open investment funds (World, Cash and EuroCash) hold 67.73\%, Erste's open investment funds (Cash, EuroCash and EuroBalanced) hold $16.38 \%$ and Kombank Invest 2.21\% (NBS, 2013). It can be explained with strong support of mother bank, which provides good customer base and joint offer to the customer for a-vista or term deposit and cash fund offer. Currently, potential customer (investor) can get higher revenue with open investment fund than with commercial bank. However, there is clear message that they do not guarantee that the customer (investor) will not lose or win the

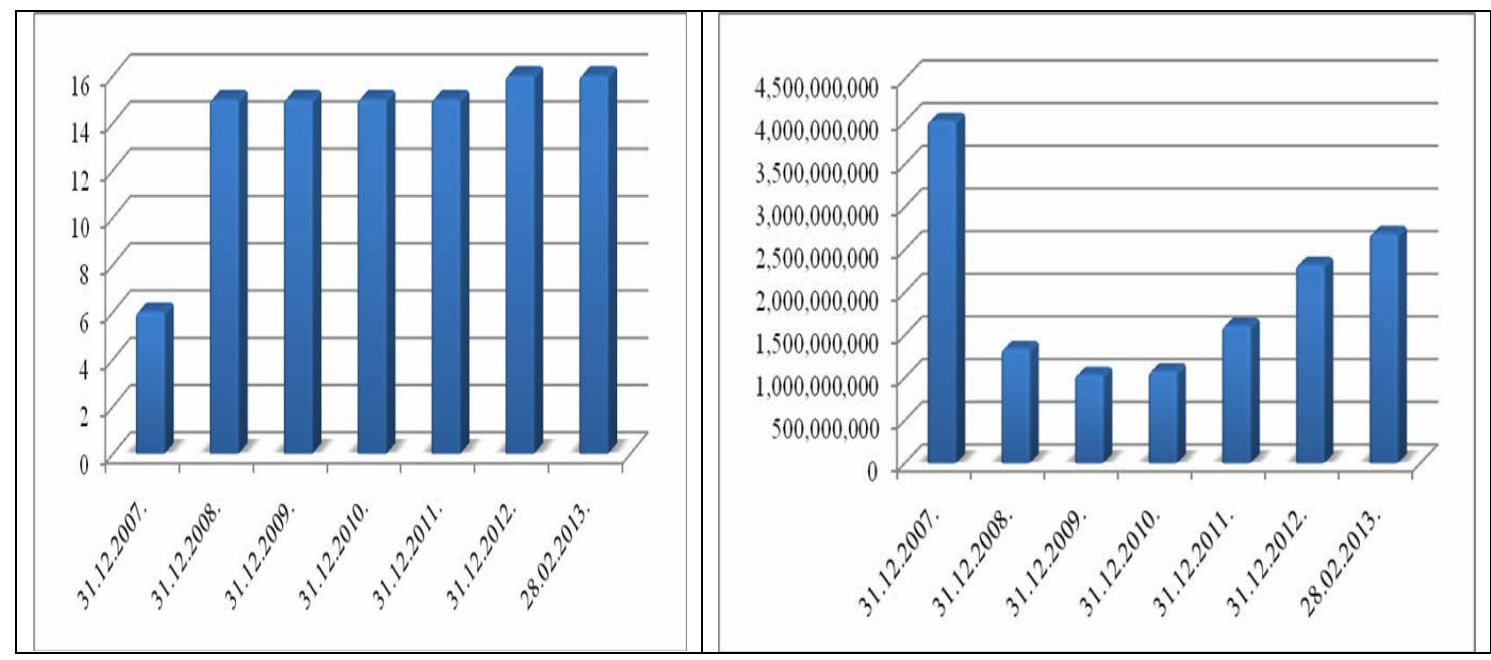

Source: Republic of Serbia Securities Commission

Figure 1. Number of open investment funds in Serbia and Value of Assets under management (20072013) 


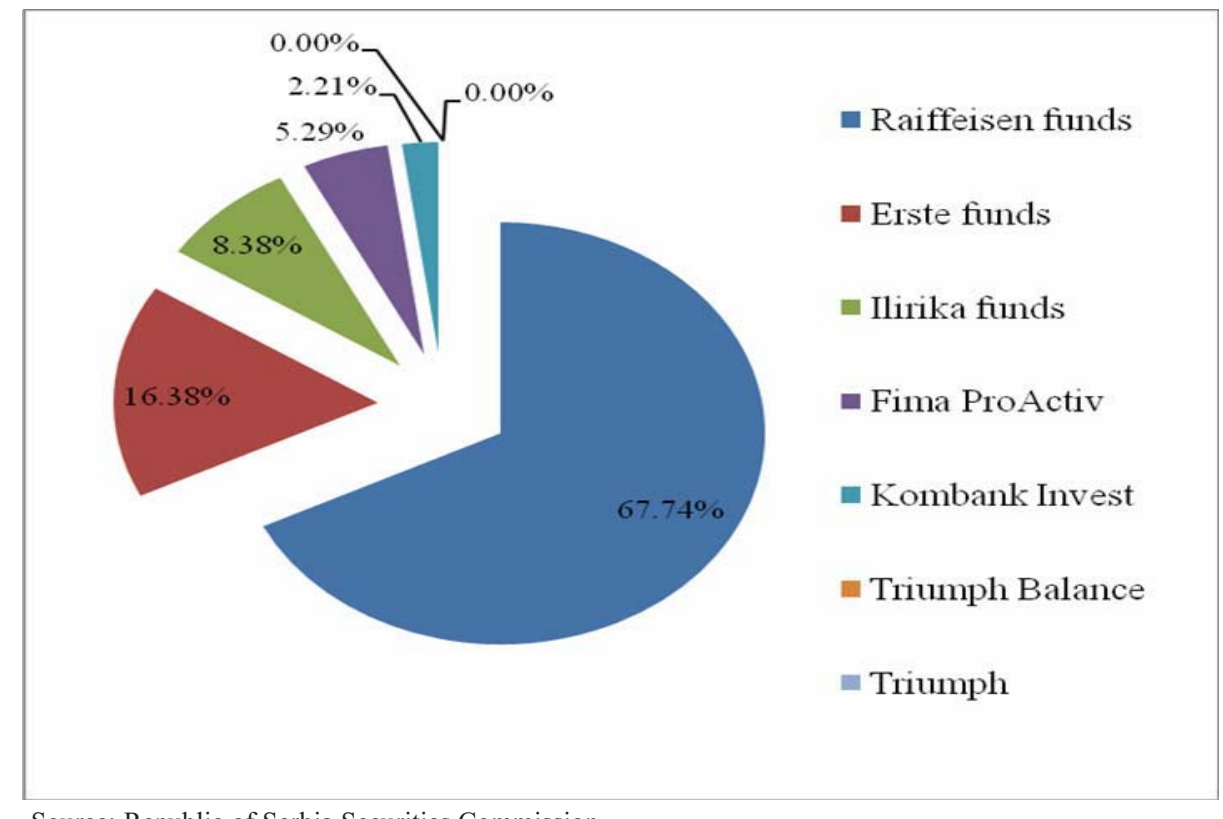

Source: Republic of Serbia Securities Commission

Figure 2. Market share of Serbian open investment funds in terms of assets under management $(02 / 28 / 2013)$

invested sum of money (Raiffeisen bank, 2013).

The second strongest group of open investment funds in terms of continuity represents funds established by Slovenian (Ilirika's funds) and Croatian (Fima) owners (individuals) of investment funds in those countries (NBS, 2013). It is important to mention that Slovenian funds expanding their activity on Serbian market on the basis of buying existing open funds, such as Delta, Citadel, Fima Novac, etc. Currently, Ilirika holds $8.38 \%$ and Fima $5.29 \%$ of Serbian market share in terms of assets under management.

It is important to say that in Serbia, the equity funds, as the most risky funds, started to operate in 2007, while cash funds (as the least risky funds) were introduced in later phase after 3 years. It is not in accordance with the world's trend. The effects of world economic crisis were visible during the second quartile of 2008. It also had bad impact on development of open investment funds in Serbia. It should be emphasized, that market trends, primarily due to the world economic crisis impact showed that the public began to lose confidence in open investment funds as a new investment alternative, which can be seen by the constant decrease in the number of investment units, the total value of property and large negative rate of return (Table 1). Number of investment units in 2007 decreased by $52 \%$ and at the end of 2010 Securities Commission has registered $1,744,493$ investment units of open funds. Value of an average investment unit followed this trend so that at the end of 2010 its value was 618.45 dinars, drop from $44 \%$ to the value at the end of 2007 . Value of an average investment unit is equal to the sum of all investment funds property divided by the number of all the investment units. In the period from the beginning of the first investment fund in Serbia to the end of 2010 
Table1. Basic indicators of open investment funds in Serbia (2007-2010)

\begin{tabular}{|l|r|r|r|r|r|}
\hline Indicators /Years & \multicolumn{1}{|c|}{$\mathbf{2 0 0 7}$} & $\mathbf{2 0 0 8}$ & $\mathbf{2 0 0 9}$ & $\mathbf{2 0 1 0}$ & $\begin{array}{l}\text { From the start of } \\
\text { the first fund }\end{array}$ \\
\hline $\begin{array}{l}\text { Number of } \\
\text { investment units }\end{array}$ & $3,644,829$ & $2,402,647$ & $2,156,867$ & $1,744,493$ & \\
\hline $\begin{array}{l}\text { Value of an average } \\
\text { investment unit } \\
\text { (dinars) }\end{array}$ & $1,107.44$ & 556.35 & 479.38 & 618.45 & \\
\hline $\begin{array}{l}\text { Total net assets OIF } \\
\text { (dinars) }\end{array}$ & $4,012,075,402$ & $1,340,474,105$ & $1,035,981,297$ & $1,078,883,380$ & \\
\hline $\begin{array}{l}\text { Returns rate o fan } \\
\text { average investment } \\
\text { unit (\%) }\end{array}$ & 11.34 & -49.76 & -13.83 & 29.01 & -37.82 \\
\hline
\end{tabular}

Source: Republic of Serbia Securities Commission

the average investment unit realised a negative return rate of $-37.82 \%$. The positive return rate of an average investment unit was recorded in 2007 and 2010, but this increase was not enough to offset a fall in 2008 and 2009. The total value of the assets of all funds in Serbia declined from about 4 billion dinars, as it was at the end of 2007 to 1 billion dinars at the end of 2010 .

Regarding the structure of the funds share in the total assets of all open funds in Serbia, it shows that four funds together hold about $63 \%$ of total assets while the other 11 funds together own a little more than a third of total assets at the end of 2010 (Table 2).
2009 and 2010 and whose assets now comprise $33.22 \%$ of total assets of all funds (most important are: Erste Cash, Raiffeisen World, Raiffeisen Cash and Citadel cash fund). In the group of balanced investment funds there are three open investment funds registered with assets of $19.97 \%$ of all open investment funds assets in Serbia (the most important are: Delta Plus, Erste Euro Balanced and Triumph Balance). Interestingly, since there are investment funds in Serbia there has been no establishment any of the returns funds.

Table 2. The participation structure of all types of open investment funds in Serbia at the end of 2010

\begin{tabular}{|l|r|r|r|}
\hline $\begin{array}{l}\text { Type of open investment } \\
\text { fund }\end{array}$ & Iumber of funds & $\begin{array}{l}\text { Assets } \\
\text { (million dinars) }\end{array}$ & $\begin{array}{l}\text { The share in the total } \\
\text { assets of all funds (\%) }\end{array}$ \\
\hline Value maintenance funds & 4 & 358 & 33.22 \\
\hline Balanced funds & 3 & 276 & 19.97 \\
\hline Returns funds & 0 & 0 & 0 \\
\hline Value growth funds & 8 & 444 & 44.30 \\
\hline Total open funds & 15 & 1078 & 100 \\
\hline
\end{tabular}

Source: Republic of Serbia Securities Commission

In the structure of the total assets of all funds dominate the value growth fund, which include nearly half the total assets of all funds in Serbia, and in this type operates the largest number of funds, eight of them (most important are KombankInFond and Triumph). Significant are also the value maintenance funds, which were developed in

\section{ANALYSIS OF BUSINESS PERFORMANCES OF OPEN INVESTMENT FUNDS IN SERBIA}

The performance analysis of the open investment funds in Serbia (13 of 15) will be made based on the Sharpe and Sortion ratios and Jensen's alpha. The analysis will be done 
for the period from 2007 to 2010 (in which the open investment funds do not have the same length of business time); due to the continuity in terms of type of funds (new law on equity markets and revised law on investment funds were brought and implemented in 2011).

Applying Sharpe ratio on open investment funds performance in Serbia, it is evident that only three open investment funds have had a positive value of this ratio, and all other funds, including the average unit of the analyzed funds achieved a negative value (Table 3 ).

A large number of funds with negative Sharpe ratio values show that there is a mismatch between total risk and funds return. Only three open investment funds have achieved rate of return above the rate recorded at the same time by risk-free asset (in Serbia a risk free interest rate is a weighted rate of return on three-month treasury bills of the Republic of Serbia), which indicates that majority of open funds in Serbia did not have return in accordance with the risks involved. Risk-free assets have had better performance than the 10 of the 13 analyzed funds.
In addition to the large negative rate of return there is another feature of the investment funds in Serbia - a total investment risk they carry, expressed through the great variability of extra returns of this investment alternative. Even nine open investment fund had a standard deviation of extra returns over $15 \%$ annually, and 5 had more than 20\%. That open investment funds in Serbia had a poor performance based on the adjustment of extra returns for the overall risk, shows the average unit of the analyzed funds. Sharpe ratio of the average unit of the analyzed funds had a negative value of -0.946 with an extra return of $-16.3 \%$ and the variability of extra return of $17.2 \%$ per year.

Ranking of the open funds according to Sharpe ratio indicates that the best performance was achieved by Citadel Novcani Fond, Erste Euro Balanced and Triumph Balanced, funds that were the only with positive ratio value. Although the Citadel Novcani Fond generated more than half less the rate of extra return than Erste Euro Balanced, its low risk expressed by the standard deviation of the extra return of only $1 \%$ per annum positioned it in the first place

Table 3. Sharpe ratio for the open investment funds in Serbia (from the beginning of their operations until the end of 2010)

\begin{tabular}{|l|r|r|r|r|}
\hline \multicolumn{5}{|c|}{ Sharpe ratio for the period from the beginning of every fund operation (annual level) } \\
\hline \multicolumn{1}{|c|}{ Name OIF } & Extra return & $\boldsymbol{\sigma}$ extra return & \multicolumn{1}{c|}{ Sharpe ratio } & \multicolumn{1}{l|}{ Rang } \\
\hline Delta Plus & -0.171 & 0.164 & -1.044 & 5 \\
\hline Delta Dynamic & -0.384 & 0.206 & -1.866 & 11 \\
\hline Erste Cash & -0.003 & 0.005 & -0.754 & 4 \\
\hline Erste Euro Balanced & 0.045 & 0.044 & 1.017 & 2 \\
\hline FimaNovac & -0.011 & 0.004 & -2.620 & 13 \\
\hline FimaProActive & -0.317 & 0.216 & -1.469 & 9 \\
\hline Citadel Novčani Fond & 0.021 & 0.010 & 2.067 & 1 \\
\hline Focus Premium & -0.439 & 0.196 & -2.239 & 12 \\
\hline Triumph Balance & 0.024 & 0.081 & 0.300 & 3 \\
\hline Ilirika Global & -0.315 & 0.220 & -1.428 & 8 \\
\hline KombankInFond & -0.193 & 0.150 & -1.281 & 7 \\
\hline RaiffeisenAkcije & -0.498 & 0.276 & -1.802 & 10 \\
\hline Triumph & -0.231 & 0.216 & -1.068 & 6 \\
\hline Average unit of the funds analyzed & -0.163 & 0.172 & -0.946 & $/$ \\
\hline
\end{tabular}

Source: Prospects of the investment funds 
according to Sharpe ratio.

An excellent example of a case in which a higher rate of return does not automatically mean better Sharpe ratio performance is the relation of open funds ranked in the first and third place. These funds had very similar rates of extra return, Citadel Novcani Fond $2.1 \%$ and Triumph Balance $2.4 \%$, but the Triumph Balance fund achieved this return with much greater variability of $8.1 \%$ compared to $1 \%$ which was achieved by Citadel Novcani Fond. Extra value achieved by Citadel Novcani Fond is the result of wise investment decisions of the fund portfolio manager. It should be taken into consideration that Citadel Novcani Fond is assets value maintenance fund and it has low variability because the majority of assets it invests in short-term debt instruments, while the Triumph Balance fund is a balanced type of fund and its standard deviation is not too large considering that part of the assets it invests in shares that have much more risk than money market instruments.

Raiffeisen Akcije open fund had the biggest risk whose standard deviation of extra return on the annual level was $27.6 \%$. It should be noted that all funds started operations at different times, and that while some funds operated, others were not established. Much greater variability had the funds that did business in other half of 2008 and the first half of 2009, because it was a period of great market decline that led to the reduction of investment units of all funds. Funds that began their work after a period of great market decline had significantly lower variability.

Based on the analysis of the performance of open investment funds in Serbia according to Sharpe ratio there is conclusion that risk and return of funds did not comply, or that the great majority of the funds has large total investment risk, and that in the past period it realized rate of return below the risk free rate.

Applying Sortino ratio on the open investment funds performance in Serbia it can be seen that only three open funds generated positive performance, and that ten analyzed funds had a bad performance. The returns of ten funds that had a bad performance by Sortino ratio were below the return of risk free rate which is set as the minimum acceptable return rate.

A large number of funds had a high risk of

Table 4. Sortino ratio for open investment funds in Serbia (from the beginning of operations until 2010)

\begin{tabular}{|c|c|c|c|c|}
\hline \multicolumn{5}{|c|}{ Sortino ratio for the period of the beginning of operation of every fund (annual level) } \\
\hline Name OIF & $\begin{array}{l}\text { Extra } \\
\text { return }\end{array}$ & $\begin{array}{c}\sigma \text { negative extra } \\
\text { return }\end{array}$ & Sortino ratio & Rang \\
\hline Delta Plus & -0.171 & 0.101 & -1.689 & 6 \\
\hline Delta Dynamic & -0.384 & 0.173 & -2.219 & 11 \\
\hline Erste Cash & -0.003 & 0.004 & -0.924 & 4 \\
\hline Erste Euro Balanced & 0.045 & 0.027 & 1.638 & 2 \\
\hline FimaNovac & -0.011 & 0.003 & -3.402 & 13 \\
\hline FimaProActive & -0.317 & 0.182 & -1.742 & 7 \\
\hline Citadel Novčani Fond & 0.021 & 0.003 & 7.588 & 1 \\
\hline Focus Premium & -0.439 & 0.165 & -2.652 & 12 \\
\hline Triumph Balance & 0.024 & 0.036 & 0.672 & 3 \\
\hline Ilirika Global & -0.315 & 0.176 & -1.783 & 9 \\
\hline KombankInFond & -0.193 & 0.108 & -1.777 & 8 \\
\hline RaiffeisenAkcije & -0.498 & 0.265 & -1.880 & 10 \\
\hline Triumph & -0.231 & 0.175 & -1.320 & 5 \\
\hline Average unit of the funds analyzed & -0.163 & 0.111 & -1.471 & 7 \\
\hline
\end{tabular}


decline expressed by the standard deviation of the negative extra returns. The greatest potential for achieving negative returns had Raiffeisen Akcije open fund whose standard deviation of negative extra return was $26.5 \%$ per annum. The great potential of achieving negative return of Raiffeisen Akcije fund was confirmed during the entire period of its business, because its investment unit lost $49.8 \%$ of its value annually. As many as 8 out of 13 open funds analyzed had the risk of decline by more than $10 \%$ and 6 funds had a risk of decline more than $15 \%$.

Mostly open funds belonging to the value maintenance funds had the low value of the standard deviation of negative extra return, and which the most of their assets invest in debt securities with a low variability of return. Very small risk of return decline had the open investment funds Fima Novac and Citadel Novcani Fond, whose standard deviation of negative return was only $0.3 \%$ annually during the entire analyzed period. Both funds are funds of assets value maintenance, which should have, because of the composition of their assets, a small negative return volatility even in the conditions of markets' decline.
Open investment funds that had the best performance by Sortino ratio were Citadel Novcani Fond, ratio value 7.588, Erste Euro Balanced, ratio value 1.638, and Trimuph Balance 0.0672. These three funds are also the only three funds with a positive ratio values. Open funds Fima Novac, Focus Premium and Delta Dynamic had the worst performance.

Taking into account the above characteristics of Jansen's alpha and investment funds markets in Serbia, the calculation was made only for 2010 (results are given Table 5).

Accordingly, only one investment fund had a positive value of Jensen's alpha, respectively, only one fund has managed to achieve a higher return than the expected rate of return according to CAPM model. All other open investment funds have failed to achieve the expected rate of return that was predicted by CAPM model. Beside the failure of the vast majority of open funds to achieve the expected rate of return, there is further concern for the fact that some funds had high negative values of alpha, which indicates that they were not even close to even realizing the expected rate of return if

Table 5. Jensen's alpha for open investment funds in Serbia for 2010

\begin{tabular}{|c|c|c|c|c|}
\hline \multicolumn{5}{|c|}{ Jensen's alpha for 2010} \\
\hline Name OIF & $\begin{array}{l}\text { Achieved } \\
\text { return }\end{array}$ & $\begin{array}{l}\text { CAPM expected } \\
\text { rate }\end{array}$ & Jensen's alpha & Rang \\
\hline Delta Plus & $3.90 \%$ & $11.04 \%$ & $-7.13 \%$ & 9 \\
\hline Delta Dynamic & $-4.62 \%$ & $11.15 \%$ & $-15.77 \%$ & 11 \\
\hline Erste Cash & $9.03 \%$ & $10.87 \%$ & $-1.84 \%$ & 5 \\
\hline Erste Euro Balanced & $14.80 \%$ & $10.45 \%$ & $4.35 \%$ & 1 \\
\hline FimaNovac & $7.87 \%$ & $10.86 \%$ & $-1.20 \%$ & 3 \\
\hline FimaProActive & $7.99 \%$ & $11.79 \%$ & $-3.81 \%$ & 7 \\
\hline Citadel Novčani Fond & $10.00 \%$ & $10.95 \%$ & $-0.95 \%$ & 2 \\
\hline Focus Premium & $-20.75 \%$ & $11.48 \%$ & $-32.24 \%$ & 12 \\
\hline Triumph Balance & $9.57 \%$ & $11.22 \%$ & $-1.64 \%$ & 4 \\
\hline Ilirika Global & $10.24 \%$ & $12.90 \%$ & $-2.66 \%$ & 6 \\
\hline KombankInFond & $0.78 \%$ & $12.78 \%$ & $-12.00 \%$ & 10 \\
\hline RaiffeisenAkcije & $-50.52 \%$ & $5.81 \%$ & $-56.33 \%$ & 13 \\
\hline Triumph & $5.08 \%$ & $10.74 \%$ & $-5.66 \%$ & 8 \\
\hline Average unit of the analyzed funds & $5.01 \%$ & $11.04 \%$ & $-6.04 \%$ & 7 \\
\hline
\end{tabular}


they are not able to exceed it. The average unit the funds analyzed had the value of Jensen's alpha $-6.04 \%$ with achieved return of $5.01 \%$ and the expected rate of return of $11.04 \%$.

All open investment funds, with the exception of Raiffeisen Akcije fund, had a similar expected rate of return that is in the range between $10.45 \%$ and $12.90 \%$. Open investment fund Raiffeisen Akcije had the expected rate of return of $5.81 \%$ and an achieved rate of up $-50.52 \%$. In contrast to the expected rate, the achieved rate of return of open investment funds in 2010 are in the range between $14.80 \%$ which is achieved by Erste Euro Balanced Fund to $-50.52 \%$ achieved by Raiffeisen Akcije fund.

Ranking performance by Jensen's alpha shows similar results as the ranking of the last two performance measures. The three highest-ranked open funds in Serbia are Erste Euro Balanced, Citadel Novcani Fond and Fima Novac. Of these three funds with the best performance only Erste Euro Balanced fund had positive Jensen's alpha value in 2010, 4.35\%. Open fund Citadel Novcani Fond needed to achieve a better return of $0.95 \%$ in order to achieve the expected rate of return and the alpha value $0.95 \%$, while open fund Fima Novac had alpha value of $-1.20 \%$.

The three lowest ranked open investment funds in Serbia, according to Jensen's alpha values in 2010 are RaiffeisenAkcije with alpha value of $-56.33 \%$, Focus Premium whose alpha value is $-32.24 \%$ and Delta Dynamic with alpha value of $15.77 \%$.

\section{CONCLUSION}

Open investment funds started to operate in Serbia in 2007. They should be investment alternative for individuals and companies. Currently, Serbian citizen in average invests 1 euro in open investment fund (Bifoline, 2012) and 1000 euro in deposit with the bank (authors calculation on the basis of available data on the site of NBS, 2012). It can be explained with the level of education of the citizens in terms of possible investment alternatives, previous experience on the market and financial (ratio) performance of open investment funds.

In the period of 2007 to 2010, open investment funds showed very negative trend of assets reduction that they managed, as well as the number of investment units they issued. The analysis, based on the use of three ratios (Sharpe, Sortino and Jensen's alpha) for measuring performance based on the (high) risk and return showed that the returns of most open investment funds in Serbia are low.

We can make a conclusion that the performance of open investment funds in Serbia is bad.

- No open investment fund had a positive value of all three indicators in the period in which it operates.

A positive value of at least one performance measure had only three open investment funds, i.e., ten open funds did not achieve a positive value on at least one performance measure.

- The results of only 15 investment funds had a positive value, i.e. only $12.8 \%$ of all the results were positive (out of 117 results of performance measurement for the entire period of operations of each fund).

- Open investment funds in Serbia have total investment risk in accordance with the analysis of the performance by Sharpe ratio.

Results of Sortino ratio suggest a high risk of open investment funds assets 
value decline, which is conditions of market decline came to the fore through the negative rates of returns of most funds (which is consistent with the analysis by Sharpe ratio).

The negative results of performance measurement in the vast majority of analyzed open funds, large total investment risk and the risk of decline, which they had, the inability to reach a risk-free rate of return and the market benchmark rate of return, indicate poor operating results of open investment funds in Serbia.

This Research Paper was the part of the project "Advancing Serbia's Competitiveness in the Process of EU Accession", no. 47028, in the period 20112015, financed by Serbian Ministry of Science and Technological Development.

\section{References}

Alexander, C. (2008). Market Risk Analysis: Quantitative Methods in Finance. Chichester, Wiley.

Barjaktarovic, L., \& Jecmenica, D. (2011). Optimism vs. pessimism of competitiveness of Serbian banking division. Industrija, 2/2011: 137-150. (In Serbian)

Barjaktarovic, L., Jecmenica, D., \& Paunovic, M. (2012). Ratio analysis of actual performances of open investment funds in Serbia. May Conference on Strategic Management, Technical faculty in Bor, 2012: 332-342. (In Serbian)

Barjaktarovic, L., Jecmenica, D., \& Paunovic, M. (2012a). Investment funds as alternative investment in Serbia, ICEOS 201213 th International Conference on Econometrics, Operations, Research, and Statistics, Turkish Republic of Northern Cyprus. (presented paper work, the book of

\title{
РАЦИО АНАЛИЗА АКТУЕЛНИХ ПЕРФОРМАНСИ ПОСЛОВАЊА ОТВОРЕНИХ ИНВЕСТИЦИОНИХ ФОНДОВА У СРБИЈИ
}

\author{
Лидија Барјактаровић, Дејан Јечменица и Маја Пауновић
}

\section{Извод}

Предмет овог рада је осврт на перформансе отворених инвестиционих фондова у Србији у периоду од 2007. до 2013. године. Применом Јенсенове алфе, Шарперовог и Сортиновог рациа је утврђено да су перформансе домаћих отворених инвестиционих фондова лоше. Сагледавање пословања инвестиционих фондова је базирано на приносима који носе и ризицима које прихватају у пословању. У Србији су фондови акција, као највисокоризичнији, почели да функционишу 2007. године, док су новчани фондови као нискоризични, основани у каснијој фази односно после 3 године. Тренутно их послује 16 (на крају другог месеца 2013.године), где доминирају фондови раста вредности и фондови очувања вредности. Укупна нето имовина отворених инвестиционих фондова је 2,3 милијарде динара, односно 20, милиона евра (на крају 2012.године).

Кључне речи: инвестициони фондови, каматне стопе, ризик, Јенсенова алфа, Шарперов рацио, Сортинов рацио 
proceedings in the process of publishing)

Doku, N.J., Delali Ajdasi, C.K., \& Sarpong-Kumankuma, E. (2011). Financial market development and capital structure of listed firms- empirical evidence from Ghana. Serbian journal of management, 6(2): 155168.

Haslem, J. (2010). Mutual Funds: Portfolio structure, Analysis, Management and Stewardship. New Jersey, Wiley.

Jensen, M. (1967). The performance of mutual funds in the period 1945 - 1965. Journal of finance 23.

Jeremic, Z. (2009). Financial markets. Third edition. Belgrade, University Singidunum. (In Serbian)

Luckoff, P. (2011). Mutual Fund Performance and Performance Persistence: The Impact of Fund Flows and Manager Changes. Geissen, Gabler Research.

National Bank of Serbia (2013). Quarterly report of movement of financial stability indicators of Repbulic of Serbia for the $4^{\text {th }}$ quartile of 2012.

National Bank of Serbia (2013) My money [www.mojnovac.rs/fondovi.1.thml]

Prospect of open investment fund Citadel Cash Fund [http://www.citadelam.com/files/Prospekti/Prospekt-Novcani31-03-11.pdf]

Prospect of open investment fund Delta Dynamic [http://www.deltainvestments.rs/ upload/images/Prospekt\%20Delta\%20Dyna micx.pdf]

Prospect of open investment fund Delta Plus [http://www.deltainvestments.rs/upload /images/Prospekt\%20Delta\%20Plusx.pdf]

Prospect of open investment fund Erste Cash

[http://www.ersteinvest.rs /Erste_CASH /Prospekt/sPortal.portal; jsessionid=hrqJL58MTvzVVfJY0w9dt1JbPt NgY6SPYbh81LKs2cXH6GnpZx7K!40756 8366?_windowLabel=LABEL_MENU\&_ur
1Type $=$ action \&LABEL_MENU_]

Prospect of open investment fund Erste Euro Balanced [http://www.ersteinvest.rs/ Erste_CASH/Prospekt/sPortal.portal;jsessio nid=hrqJL58MTvzVVfJY0w9dt1JbPtNgY6 SPYbh81LKs2cXH6GnpZx7K!407568366? _windowLabel=LABEL_MENU\&_urlType $=$ action\&LABEL_MENU]

Prospect of open investment fund Fima Novac [http://www.fimainvest.com/ download/Prospekt $\%$ 20FIMA\%20NOVAC \%2031.12.pdf]

Prospect of open investment fund Fima Proactive [http://www.fimainvest.com/ download/Prospekt $\% 20$ FIMA\%20ProActive $\% 2031.12 . p d f]$

Prospect of open investment fund Ilirika global[http://www.mojnovac.rs /upload/ documents/prospekti_prezentacije/ ilirika/ PROSPEKT_-_ILIRIKA_GLOBAL.pdf ]

Prospect of open investment fund Kombank In Fond [ http://www. kombankinvest. com/ pdf/InFond_duzi 2.pdf]

Prospect of open investment fund Raiffeisen Shares [http:// www.raiffeiseninvest .rs /bgrbaiinv/ web/ public/ prospekt]

Prospect of open investment fund Triumph [http://www.mojnovac.rs/ upload /documents/prospekti_prezentacije/truimph/ Prospekt-OIF-31-08-10.pdf]

Prospect of open investment fund Triumph Balance [http://www.citadelam.com/files/Prospekti/Prospekt-Balans-3103-11.pdf]

Prospect of open investment fund Focus Premium [http://www.citadel-am.com/files /Prospekti/Prospekt-Premium-31-08-10.pdf]

Racic, Z., Barjaktarovic, L., \& Zeremski, A. (2011). Analysis of debts on profitability of Serbian successful companies during the crisis, Industrija 3/2011: 45-59. (In Serbian) 
Security Commission of Republic of Serbia (2008) Report on activities of Security Commission of Republic of Serbia and movements on organized Serbian security market in period January December 2007. Belgrade.

Security Commission of Republic of Serbia (2009) Report on activities of Security Commission of Republic of Serbia and movements on organized Serbian security market in period January December 2008. Belgrade.

Security Commission of Republic of Serbia (2010) Report on activities of Security Commission of Republic of Serbia and movements on organized Serbian security market in period January December 2009. Belgrade.

Security Commission of Republic of Serbia (2011) Report on activities of Security Commission of Republic of Serbia and movements on organized Serbian security market in period January December 2010. Belgrade.

Sharpe, W. (1966). Mutual fund performance. Journal of business, vol. 39.

Sortino, F., \& Satchell, S.(2001). Managinig downside risk in financial markets. Oxford, Butterwoth-Heinemann.

The Investment Company Institute (2007) A guide to understanding mutual funds. Washington DC, ICI.

The Investment Company Institute (2011) 2011 Investment Company Fact Book. 51. edition. Washington DC, ICI.

The official gazette of Republic of Serbia (2011) Law on Investment funds [www.sec.gov.rs]

The official gazette of Republic of Serbia (2011) Law on equity markets [www.sec.gov.rs]

The site of Bifoline (2012) News [www.bifoline.rs]
The site of Raiffeisen bank a.d. Belgrade (2013) Investment funds [www.raiffeisenbank.rs]

The site of Security Commission of Republic of Serbia (2013) Participant on Serbian financial market [www.sec.gov.rs]

Vejnovic, N. (2011). Analysis of performance of Serbian investment funds, FEFA, Belgrade. (In Serbian) 